\author{
Jerzy Sierociuk \\ Adam Mickiewicz University in Poznań \\ Institute of Polish Philology \\ ORCID: 0000-0001-9069-6117; e-mail: jasier@amu.edu.pl
}

\title{
A centennial of dialectology in Poznań
}

\begin{abstract}
This article presents the most relevant information on the history of dialectological research in Poznań and its context, the academic achievements of the Poznań University enjoyed in cooperation with the Poznań Society for the Advancement of Arts and Sciences. The two institutions have greatly contributed to the development of Polish studies including dialectology.

The presented information pertains chiefly to the relatively unknown accomplishments of the dialectology team, for example a phonographic archive containing recordings of utterances of informants born in the second half of the $19^{\text {th }}$ century (the oldest interlocutor was born in 1855). Together with contemporary recordings, the collection contains approximately 3,700 hours of rural speech. The entire archive is available in a digital version.

The text is supplemented with information about the history of Poznan dialectology and the contemporary activities of the team of the Dialectology Workshop at the Poznan University, mainly lexicographic works.
\end{abstract}

Key words: history of dialectology in Poznań, Polish studies at the AMU, Poznań Society for the Advancement of Arts and Sciences, lexicography of Wielkopolska dialects.

\begin{abstract}
Abstrakt: Sto lat dialektologii w Poznaniu. W artykule przedstawione są najważniejsze informacje dotyczące historii badań dialektologicznych w Poznaniu. Podano też istotne dane, szkicując kontekst tych działań - działalność naukowa Uniwersytetu Poznańskiego ściśle powiązana jest z Poznańskim Towarzystwem Przyjaciół Nauk. Te dwie instytucje naukowe mają wielkie zasługi w rozwoju studiów polonistycznych, a w tym dialektologii.

Przedstawione informacje dotyczą głównie mało znanych osiągnięć zespołu dialektologicznego - między innymi archiwum fonograficznego $\mathrm{z}$ rejestracjami wypowiedzi informatorów urodzonych w drugiej połowie XIX wieku (najstarszy rozmówca pochodzi z roku 1855), co z nagraniami współczesnymi daje w sumie zarejestrowanych około 3700 godzin mowy ludowej - całość tego archiwum dostępna jest w wersji cyfrowej. Tekst uzupełnia garść informacji o historii dialektologii poznańskiej, kończy zaś szkic współczesnych działań zespołu Pracowni Dialektologicznej UAM - głównie prac leksykograficznych.
\end{abstract}

Slowa kluczowe: historia dialektologii w Poznaniu, polonistyka na UAM, Poznańskie Towarzystwo Przyjaciół Nauk, leksykografia gwar Wielkopolski.

The Poznań University could not have been founded before Poland regained independence in 1918. Therefore, the history of the university started formally in 1919 when the Piast University was established and renamed in 1920 the Poznań University. Since 1955 it has operated as Adam Mickiewicz University in Poznań (AMU). 
For years, the Poznań community strived to establish a university. The first efforts were made before the first Partition of Poland (1772).

In 1519, the Lubrański Academy was founded which boasted the title of Academia Posnaniensis and is now regarded the beginning of the Poznan academic tradition. The school was among the first in Poland to offer modern, humanistic education, diverging from the medieval scholastic model of teaching (Kaniewska 2018, 11).

In the early $17^{\text {th }}$ century, in 1611 king Sigismund III Vasa granted the Poznan Jesuit college (established in 1573) with a privilege and thus upgraded it to the rank of an academy. Unfortunately, the founding edict was not signed by the pope, allegedly due to the protests of the Krakow Academy (Kaniewska 2018, 12).

Poznan did not enjoy a university at the time of the First Polish Republic. Following the Partitions of Poland, the Prussian authorities were approached in this matter shortly after the Congress of Vienna but it did not bring about the expected results. The efforts aimed at establishing a university in Poznań

started at the time when the Grand Duchy of Posen was to be created and a petition was filed in Berlin on 3 May 1819, repeated at meetings of the national assembly held in 1827 and 1839. The argument put forward repeatedly by the applicants was the right of Polish people to create a department of the Polish language and literature. The Prussian authorities kept dismissing the argument by replying that the department could be established in the already existing universities in the other Prussian cities (Wrocław, Kaliningrad, Berlin) (Maciejewski 2018, 26).

Consequently, the Poznań university was not established during the Partitions of Poland. The early $20^{\text {th }}$ century marked construction of buildings erected with the Royal Academy in mind, a substitute of a Prussian university. The complex of buildings boasts a concert hall with very good acoustics used for philharmonic performances (including the International Henryk Wieniawski Violin Competition) and the Rector's offices. However, these efforts on the part of the Prussian authorities were aimed at transforming Poznań into the Kaiser's Residenzstadt (city of residence). Back then, in 1902-1918, after dismantling the city fortifications, the so-called castle district was built with buildings partly used by the University today. The building of the former Colonisation Committee calls for special attention as the contemporary seat of the Faculty of Polish and Classical Philology of the AMU. This is an example of the meanders of history: the building of an institution established by the Prussian authorities to fight anything Polish now host the rooms and laboratories dedicated to Polish studies, oftentimes considered the best in the country.

As a young university, Poznań faced problems with shortages of academic teachers. In the faculty of Polish philology, linguists were the hardest to find.

When the classes started, the faculty of the Polish language at the Poznan University was not (...) staffed and starting in the $3^{\text {rd }}$ semester, the lectures were conducted by proxy by 
Dobrzycki, Lehr and Rudnicki in their respective fields of study. It was not until January 1922 when Edward Klich, Ph.D., a "substitute professor" from Krakow took over lectures in the faculty. In March 1922, there was an exchange between Lvov and Poznan at the faculty of Slavic philology. Tadeusz Lehr-Spławiński left Poznań for Lvov; after his departure Kazimierz Nitsch taught Polish dialectology in Poznań for one trimester. After August 1922, Prof. Henryk Ułaszyn from Lvov headed the faculty of Slavic philology in Poznań (Maciejewski 2018, 56-57).

Poznań was also at a disadvantage when it came to attracting teachers, losing to the universities in Lvov, Warsaw and Krakow. A good example is Kazimierz Nitsch who initially accepted a proposal of heading the faculty of the Polish language at the Poznań University but ultimately chose the faculty of Slavic philology in Krakow (Maciejewski 2018, 57). In these circumstances, from the beginning of his stay in Poznań, Edward Klich managed linguistics"; his "academic achievements (...) were inspired by dialectology, an always present and sometimes the prevailing current" (Walczak 2018a, 252).

Over time, the Poznan University reinforced its position as an academic centre; other faculties were also developed. The graduates of the PU contributed to deciphering the code of the Enigma machine, the German encryption device. The high level of academic mathematics and an excellent command of the German language (a phenomenon still observed in the oldest inhabitants of Wielkopolska) paved way for the success of the decryption team consisting of students of mathematics. Now the university has made available the Centre for the Enigma Machine, more frequently referred to as the Museum of the Enigma Machine, documenting the huge success of the university's graduates in the form of their contribution to precipitating the end of WWII.

Over the years, the faculty of the Poznan University incorporated its graduates, among them Adam Tomaszewski, Ph.D. Born in Wielkopolska, he laid the foundations for dialectology and its dynamic development at the PU (Kobus 2017; Lewaszkiewicz 2018). Nevertheless, as the faculty was still understaffed, "visiting lectures" were the order of the day. K. Nitsch's stay, albeit short, definitely affected the methodological assumptions of dialect studies adopted in Poznań; the Krakow scholar discovered and appreciated here the young A. Tomaszewski. These relations must have contributed in the future to the methodological impact of the "Krakow school" on the research carried out by representatives of Poznan dialectology managed in the second half of the $20^{\text {th }}$ century by Prof. Zenon Sobierajski, a disciple of A. Tomaszewski. While the methodological contribution of K. Nitsch to the dialectological level is undisputable; there were more contributors.

\footnotetext{
${ }^{1}$ Of interest to the history of the Polish studies in Poznań is a work by J.F. Karskiy from E. Klich's book collection; beside the owner's autograph the book bears traces of the German occupation. This specimen of bibliophilia has been in my possession for some time. Yefim Fyodorovich Karskiy (1860-1931) was a Belarusian linguist and ethnographer. In 1893-1915, he stayed in Warsaw where he was elected twice (in 1905 and 1908) rector of the Warsaw Imperial University (Императорский Варшавский Университет).
} 
Fully organised, systematic, world-level academic and teaching activities in the realm of Polish, Slavic and Indo-European linguistics in Poland did not start until the time of Rozwadowski, Nitsch and Łoś. It was a stroke of good fortune that these three scholars could cooperate for some time in one location, creating a linguistic academic centre (the so-called "Krakow school of linguistics"). The results of this cooperation were soon tangible. A majority of the next generation of Polish linguists were either their immediate students or related to them in some way or another even if educated at other universities [bolded by JS] (Piwowarczyk 2020, 135).

In the Interwar period, dialectology was developed at the Poznan University by E. Klich but more frequently associated with the development of the discipline in Poznan is A. Tomaszewski, born in Łopienno, Wągrowiec county in Wielkopolska. However, neither of them had an opportunity to continue their research after WWII which they did not survive. E. Klich was the first Polish professor to be shot soon after Germans invaded Poznań (Walczak 2018a); A. Tomaszewski died in the last days of the war on his way home from a liberated concentration camp (Lewaszkiewicz 2018).

Despite the German repressions, the Poznan circles of academics were involved in the tertiary level of education. The University of the Western Territories was in operation, probably outside of Poznań (Wikarjak 1972) which is evidence of the local demand for a university irrespective of the circumstances.

After WWII, the Poznań University developed dynamically, and dialectology was not an exception from the rule. In this context, the following information will be of importance: the establishment of the institution, since 1955 referred to as Adam Mickiewicz University in Poznań which has been lately considered among the big three Polish universities; the Poznan faculty of Polish studies is considered the best in the country; the Poznań dialectology is among few faculties enjoying a separate organisational unit. Since 1974 it has been an independent Institute of Polish Dialectology, transformed into the Dialectology Workshop (the subject is discussed in the subsequent part of the article).

It would be impossible to present the Poznan university without referring, even briefly, to the achievements of the Poznan academics. As there was absolutely no hope for establishing a university, the community in Wielkopolska founded the Poznan Society for the Advancement of Arts and Sciences (PTPN) which started operation on 13 February 1857. The founders of the Society intended to protects and develop the endangered national culture. To some extent, the Society replaced a university, by animating the scholarly life in this part of Prussia. Organised faculties were involved in regular academic research; a library collected many specimens of Polish literature, invaluable to Polish culture. The library boasts priceless collections of books donated to the Society by its members, especially at the beginning of the Society's operations. At present, the collection grows mainly as a result of a (typically international) exchange of books between libraries and profiled purchases. As a result of a very good tradition, despite the harm inflicted by the two world wars, the Society's library is an excellent place of work for people interested in broadly defined humanities.

The PTPN attracted not only people involved in protecting Polish culture in the Prussian territory. The Society was partly responsible for the success of preventing Germanisation; statistics provide compelling evidence of that: 
"According to data from 1846, the Great Duchy of Posen was inhabited by $1,342,000$ people including 841,000 Poles (63\%), 420,000 Germans (31\%) and 81,000 Jews (6 \%).

In 1905 , the numbers were as follows: $1,990,000$ people, including $1,220,000$ Poles $(61 \%)$, 770,000 Germans (39\%); the latter number contains all the Jews.

This is an indication that nearly 100 years of Germanisation did not bring about much effect" (Jędraszewski, Szczepaniak 2010, 9).

German materials related to the nationality issues in some parts of Wielkopolska also provide a specific image. According to the research carried out by Stanisław Malepszak, German documents prove unambiguously that in 1918, Bukówiec Górny (and many neighbouring villages in Leszno county) was inhabited exclusively by Poles. However, this does not mean that it was a standard situation in the area (Malepszak 2007, 207). The specific distribution of Germanisms in the local dialects comes as no surprise; areas of intensive Prussian colonization do not show deep concentration thereof in the local dialects (Gliszczyńska 2007, 280).

In these circumstances, the Poznań Society for the Advancement of Arts and Sciences could not do anything but get involved in creating a new university. The Society provided the first teachers and rectors of the Poznan university.

The Society's Publishers have greatly contributed to promoting issues of dialectology and the achievements of Poznań dialectologists. In 1960, the Society reactivated publishing "Slavia Occidentalis", a journal dedicated to issues of the language and culture of western Slavs. It has presented many articles dedicated to analyses of various aspects of Wielkopolska and other dialects. The Publishers launched to the market a lengthy Questionnaire to the Atlas of Wielkopolska's folk language and culture (Sobierajski 1972). "Gwary Dziś" ["Dialects Today"] have been connected with the PTPN since the very beginning - initially as a series of materials on international conferences co-organised with the Institute of Polish Philology of the Poznań University, entitled "Dialects Today"; since 2015 it has been an online annual dedicated to Slavic dialectology (http://gwary.ptpn.poznan.pl/pl/index-pl/). Notably, the boosted international prestige reflected in, among other things, a growing number of foreign participants of the conferences has opened up an opportunity for the Poznań scholars to submit an application to the $14^{\text {th }}$ International Congress of Slavists in Ohrid (2008) for affiliation at the International Committee of Slavists of the Dialectology Committee.

Dialectology at the Poznan University developed in two ways: the basic current stems from activities instigated by Ludwik Zabrocki who "Back in (August) 1946 (...) started to organise a suitable research centre, informally referred to as the "Phonographic Archive". At the development phase, the centre operated as part of the Western Slavic Institute" (Nowak 2001, 201). Officially, the centre was called the Phonographic Archive of the Western Slavic Institute of the Poznań University. In the subsequent years it was renamed the Phonographic Institute of the Poznań University (after 1951), the Phonographic Workshop at the Faculty of the Polish Language of the PU (after 1952), the Workshop for Archiving Dialects at the Faculty of General Linguistics of the AMU (1960-1969), the Institute of Polish Dialectology (Nowak 2001, 202-203) affiliated with the Institute of Polish Philology of the AMU (1974-2009) and, finally, the Dialectology Workshop at the IPP AMU (since 2009). This is the "lineage" of 
contemporary dialectological research at the Poznań University. This tradition of dialectology, exceeding Polish studies, has been continued and reflected in the arrangement of the rooms. Before relocation to a building at ul. Fredry 10, dialectology was located in the old seat of the Polish studies in Collegium Novum, on the last floor together with German studies while the Polish studies were located below, on the second and third floor. Today, our rooms are also located in the loft ( $4^{\text {th }}$ floor) which has its advantages because the lower floors and the "broken" space do not interfere with listening to the recordings taken during field studies.

The Poznań dialectology has made a significant contribution to the achievements of scholars related by structure to Polish studies. After WWII, Prof. Stanisław Urbańczyk played an important role in developing the linguists dealing with Polish studies, including dialectology. He stayed in Poznań in 1947-1956 and served even as a dean. Prof. Monika Gruchmanowa and Prof. Zygmunt Zagórski were other contributors, propagating knowledge of the (mostly systemic) complexity of Wielkopolska dialects among "Polish" scholars. They wrote monographs of the dialects spoken in western Wielkopolska (Gruchmanowa 1970) and northern Wielkopolska (Zagórski 1967). They also contributed to the publication of the Atlases of the folk language and culture of Wielkopolska (the subject is discussed in the subsequent part of the article).

More information on the development of Polish linguistics (including dialectology) at the AMU is presented Z. Zagórski (Zagórski 2011) while B. Walczak (Walczak 2018b, 303-306) has compiled a list of professors with a special impact on the development of the Poznan teachers of Polish studies.

Research into Wielkopolska dialects is of importance not only in the context of general characteristics of Polish and Slavic dialects. Perhaps even more important is documenting them because of their role in shaping the national language (and culture). What is more, the peripheral location of Wielkopolska on a linguistic map of Poland (and the Slavic world) has resulted in the existence of many archaic elements, the so-called peripheral archaisms which give insight into old language structures. They provide evidence of the native origin of some words (e.g. murzyn [a black person] 'one who is darkened, dark' < Wielkopolska dialect murzyć 'to blacken' (Sierociuk 2005)), bystry 'bright' (bystre stońce, bystra sukienka), kromka 'a lateral part or end of a whole' (not only kromka chleba 'the first or last piece of a loaf of bread' unlike in the general language: 'a subsequent sliced piece of bread from its central (soft) part') kromka kopca, kromka materiatu (sartorial: 'a strip of fabric, narrow - on the sides - when unrolled from a bolt') etc. Many confirmations do not appear until intense field explorations. In a majority of cases, these are words without lexicographic documentation, therefore often they are not present in linguistic research awareness.

As a result of historical developments, in the early stage of documenting the language spoken in Poland's rural areas, Wielkopolska dialects did not enjoy special interest (Sierociuk 2013). Hence the documentation deficit, reflected also in the latest general Polish Dictionary of Polish Dialects (SGP). An analysis of the dictionary material confirms the status well recognised by circles of dialectologists, expecting that the gaps will be bridged soon (Karaś 2011, 58, 293). Excerpts from the work of Oskar Kolberg (Kolberg 1875-1882) and A. Tomaszewski’s notes from 1930-1932 (Sierociuk 
2019b) do not provide a basis for characterising Wielkopolska dialects, let alone observing the change dynamics.

The post-war period in the history of Poznań dialectology was marked by intense activities in the area of documenting the collection of Wielkopolska dialects. From the beginning of the team archiving the language spoken by people in rural areas, the field documentation was extended by initially several-minute-long recordings on acetate discs, later on magnetic tape and, finally, registered in a digital format. In 2001, Prof. Henryk Nowak, the then manager of the Polish Dialectology Unit, wrote in an act of handing over the responsibility for the subsequent development of Poznan dialectology:

The Unit of Polish Dialectology has at its disposal (...) phonographic dialectal texts from 520 villages from various regions in Poland. (...) These phonic archived dialectological material, expressed in time units, offers in total approximately 520 hours of recordings of language of villagers (Nowak 2001, 205).

The mentioned materials are the most valuable because of the time when they were recorded and the characteristics of the respondents. Let me provide some data:

The oldest recording was made as early as on 8 August 1945; Tadeusz Wronkowski's interlocutor was a male inhabitant of Poznań, born in 1918. The entire documentation is 44'37' long. By 1947, more recordings were made (ranging from 19'56" to 40 '00"). Later (and very systematically) the dialects from various regions (mainly the vicinity of Złotów but also individuals repatriated from Romania together with inhabitants of Czech cities: Brno, and Albanian - including Tirana) were recorded by Professor L. Zabrocki, the founding father of the Poznań archive. After 1949, Z. Sobierajski, Ph.D. was in charge of obtaining dialectal texts. Due to the limited capacity of the discs, initially some utterances did not exceed 4-5 minutes. Of course, in a specific village several discs were recorded. As more equipment was purchased for the Poznań team, the duration of the recording grew (still on discs). At present, all the materials (the oldest and the latest alike) have been digitalized. In the new catalogue, each item takes into account a number of parameters which were at some point included into the methodological assumptions adopted by the team (Sierociuk 2003).

The oldest informant whose uttering is stored in the archive of the Dialectology Workshop of the AMU, was born in 1855 (sic!); it was a male inhabitant of Bukowska Wola near Miechów in the Krakow region. In total, Z. Sobierajski recorded 52'40" of the informant's utterances. Let me provide more extracts from the catalogue (recordings mainly from Wielkopolska) to exemplify the value of the archived materials:

- informant born in 1860; Nowa Wieś Królewska near Września (71'10”),

- informant born in 1862; Dąbrowa near Wieluń (35'46"),

- informant born in 1864; Mańkowice near Nysa (04'38'),

- informant born in 1866; Kawęczyn near Szczytno (09'08'),

- informant born in 1866; Drawsko near Czarnków (58'36”);

- informant born in 1866; Wyszyny near Chodzież (53'25'),

- informant born in 1866; Morzewo near Chodzież (29'47'),

- informant born in 1867; Wijewo near Leszno (63'26'),

- informant born in 1868; Królikowo near Żnin (30'43”). 
\& গิ

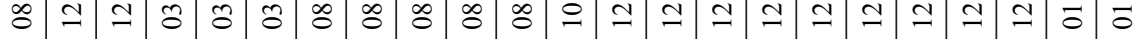
年

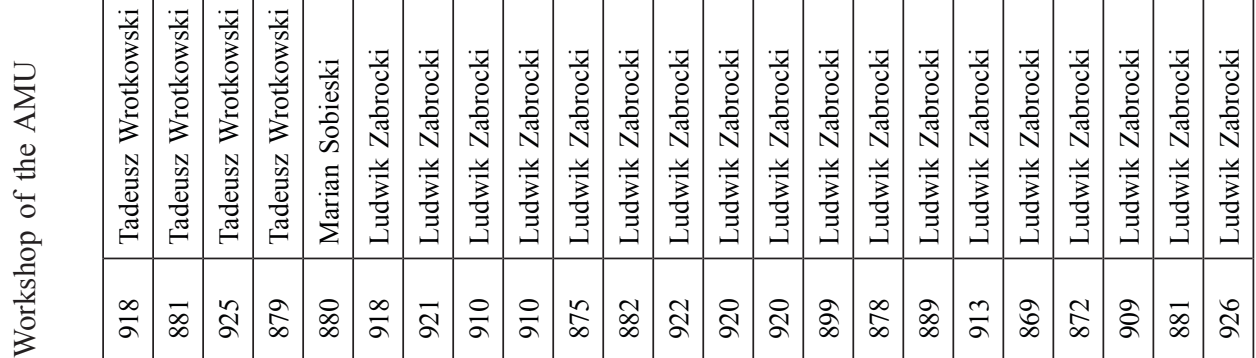

$\frac{\sqrt{0}}{\frac{0}{0}}$

$\stackrel{9}{\ddagger}$

4

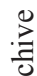

ฮี

:

क्त्र

을

$\frac{1}{2}$

$\stackrel{0}{ \pm}$

.

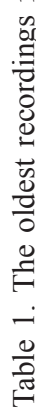

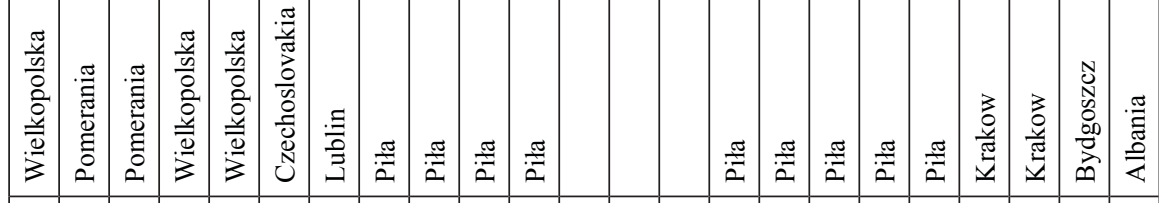

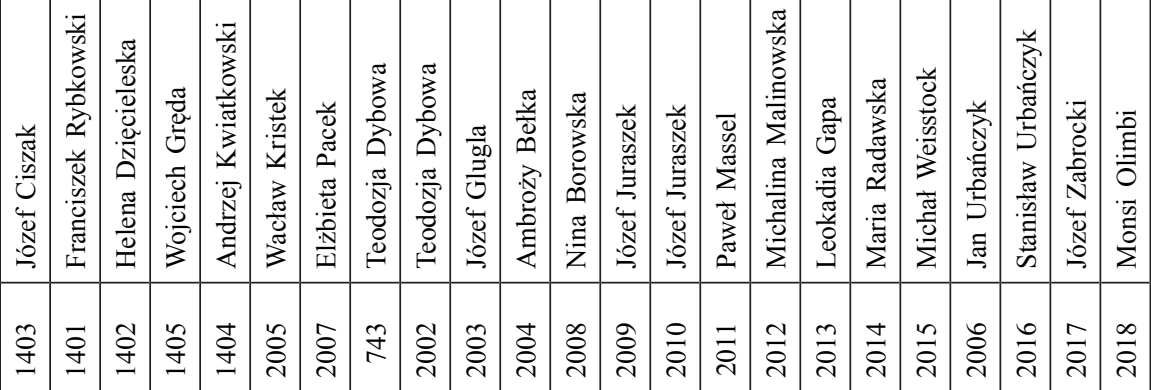

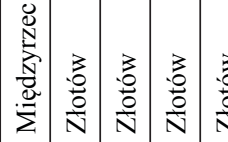

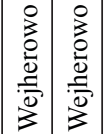

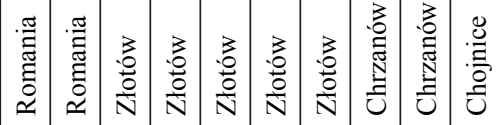

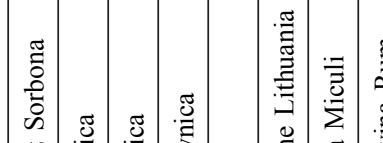

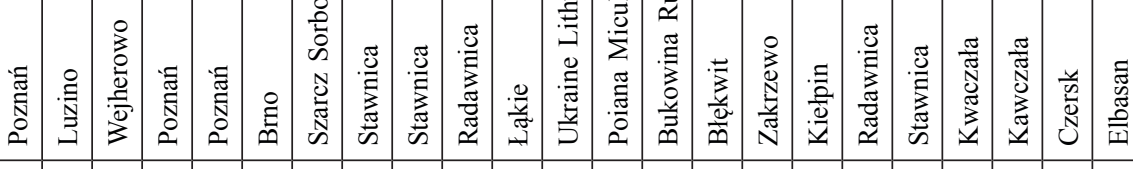

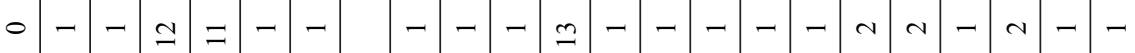




\begin{tabular}{|c|c|c|c|c|c|c|c|c|c|c|c|c|c|c|c|c|c|c|c|}
\hline $\begin{array}{l}b \\
b \\
g\end{array}$ & $\begin{array}{l}n \\
\vdots \\
0 \\
o \\
0\end{array}$ & $\begin{array}{l}\infty \\
\Xi \\
0 \\
g \\
=\end{array}$ & $\begin{array}{l}2 \\
\vdots \\
g \\
g \\
\sigma\end{array}$ & 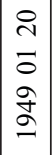 & 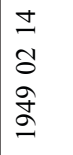 & $\begin{array}{l}n \\
0 \\
2 \\
a \\
a \\
a\end{array}$ & 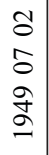 & $\begin{array}{l}2 \\
0 \\
5 \\
a \\
2\end{array}$ & $\left|\begin{array}{l}2 \\
0 \\
0 \\
a \\
o \\
2\end{array}\right|$ & $\begin{array}{l}2 \\
0 \\
0 \\
a \\
o \\
a\end{array} \mid$ & 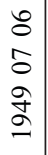 & 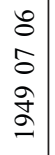 & 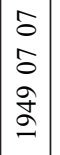 & $\begin{array}{l}0 \\
0 \\
0 \\
\text { aे } \\
0\end{array}$ & $\begin{array}{l}5 \\
0 \\
0 \\
a \\
0 \\
0\end{array}$ & $\begin{array}{l}\infty \\
0 \\
0 \\
o \\
o \\
0 \\
0\end{array}$ & 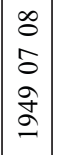 & \begin{tabular}{l}
$\infty$ \\
0 \\
0 \\
0 \\
\multirow{2}{\sigma}{}
\end{tabular} & $\begin{array}{l}0 \\
\hat{0} \\
a \\
a \\
0\end{array}$ \\
\hline & 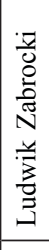 & 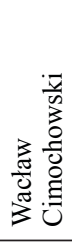 & 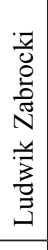 & 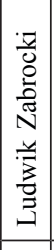 & 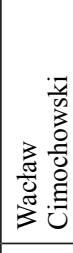 & 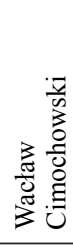 & 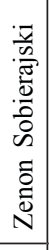 & 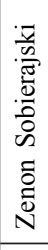 & 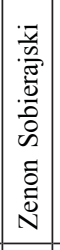 & 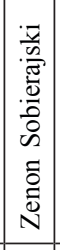 & 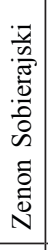 & 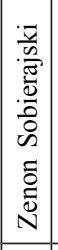 & 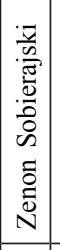 & 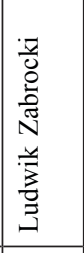 & 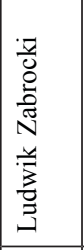 & 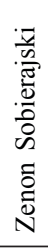 & 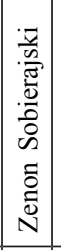 & 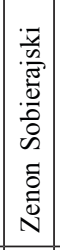 & 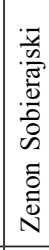 \\
\hline$\stackrel{\Xi}{\Omega}$ & $\tilde{\Omega}$ & $\frac{m}{a}$ & $\stackrel{\Xi}{\Omega}$ & $\vec{\Omega}$ & $\begin{array}{l}\infty \\
\infty \\
-\infty\end{array}$ & న్ & & $\begin{array}{l}\infty \\
\infty \\
\infty \\
-1\end{array}$ & 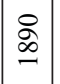 & $\mid \begin{array}{l}\infty \\
\infty \\
\infty\end{array}$ & $\stackrel{+}{\infty}$ & $\vec{\nabla}$ & 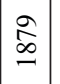 & $\stackrel{\circ}{\infty}$ & ڤे & $\begin{array}{l}\infty \\
\infty \\
\infty\end{array}$ & $\left|\begin{array}{l}\infty \\
\infty \\
-1\end{array}\right|$ & $\begin{array}{l}\infty \\
\infty \\
\infty\end{array}$ & $\stackrel{\circ}{\circ}$ \\
\hline 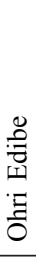 & 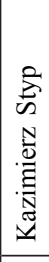 & 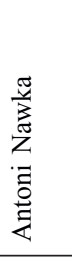 & 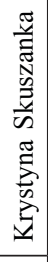 & 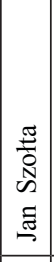 & 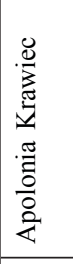 & 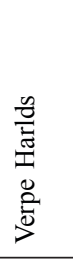 & 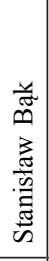 & 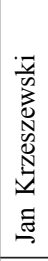 & 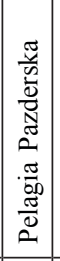 & 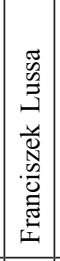 & 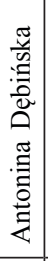 & 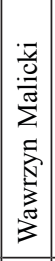 & 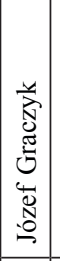 & 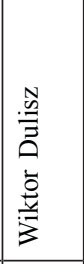 & 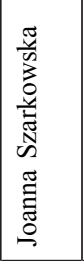 & 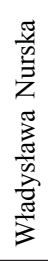 & 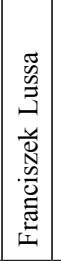 & 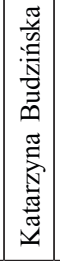 & 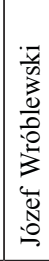 \\
\hline$\stackrel{\vec{\sim}}{\stackrel{\sim}{2}}$ & $\overline{\widetilde{d}}$ & ণิ & તิ & ڤิ & さ્ડ & ¿̊ి & $\stackrel{\infty}{\sim}$ & 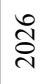 & 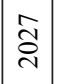 & 文 & ટે & 灾 & $\overrightarrow{\tilde{\delta}}$ & 号 & ิㅗㅇ & ڤి & ஸे & 离 & กิ \\
\hline 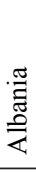 & 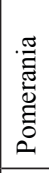 & 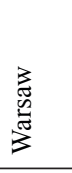 & 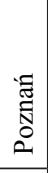 & 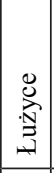 & $\begin{array}{l}\frac{\pi}{\underline{4}} \\
\frac{0}{0} \\
\frac{0}{0} \\
\frac{0}{0} \\
\frac{0}{3} \\
3\end{array}$ & 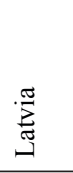 & 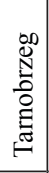 & 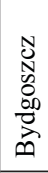 & 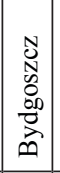 & 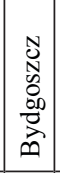 & 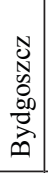 & 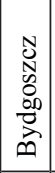 & 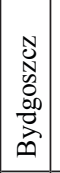 & 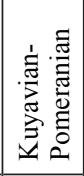 & 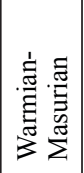 & 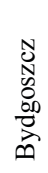 & 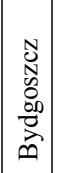 & 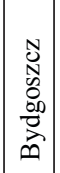 & $\begin{array}{l}\text { N } \\
N \\
0 \\
0 \\
0 \\
0 \\
0 \\
0\end{array}$ \\
\hline & 莡 & 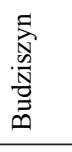 & & 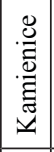 & 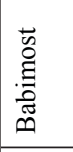 & & 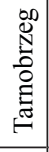 & 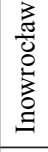 & 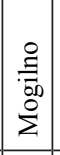 & 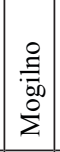 & $\begin{array}{l}\stackrel{0}{\leftrightarrows} \\
\stackrel{0}{0.0} \\
\stackrel{0}{\Sigma}\end{array}$ & $\left|\begin{array}{c}0 \\
\frac{9}{50} \\
\stackrel{0}{\Sigma} \\
\end{array}\right|$ & $\left|\begin{array}{l}0 \\
\stackrel{\vdots}{500} \\
\sum^{0} \\
\Sigma\end{array}\right|$ & 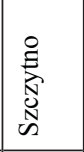 & 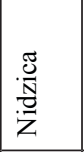 & 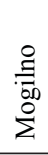 & 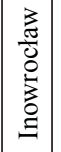 & 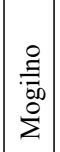 & 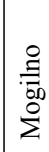 \\
\hline 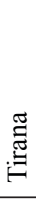 & $\begin{array}{l}\frac{\pi}{3} \\
\frac{0}{0} \\
\frac{0}{2} \\
\frac{0}{2}\end{array}$ & 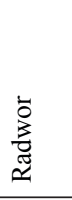 & 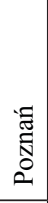 & $\begin{array}{l}\overrightarrow{0} \\
\frac{3}{0} \\
\frac{3}{3} \\
0 \\
0 \\
\frac{0}{\omega}\end{array}$ & 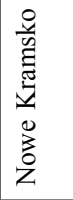 & 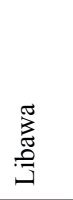 & 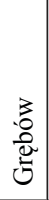 & 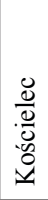 & 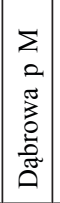 & 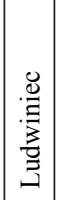 & 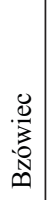 & 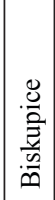 & $\left|\begin{array}{l}0 \\
\tilde{z} \\
\tilde{0} \\
\tilde{z} \\
\tilde{\widetilde{Z}}\end{array}\right|$ & 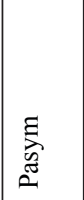 & \begin{tabular}{|l}
$\frac{\lambda}{2}$ \\
$\frac{0}{0}$ \\
0 \\
3 \\
3
\end{tabular} & 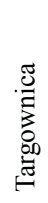 & 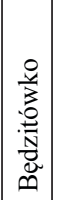 & 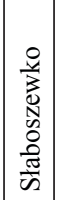 & 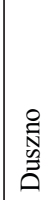 \\
\hline & - & - & $r$ & - & - & - & & - & - & - & - & - & - & $N$ & - & - & - & - & - \\
\hline
\end{tabular}


Let me also present excerpts from the earliest reports. The columns present the following information from a recently compiled catalogue: the subsequent number of recording-discs (CDs in the latest archive) from a specific village; place of recording; county (according to the old administrative division); region (overlapping with the administrative units - provinces); the subsequent number of the $\mathrm{CD}$; the informant ${ }^{2}$; the informant's year of birth; date of recording.

Specifying the age of the interlocutors is of importance not only to researchers interested in the dynamics of linguistic changes taking place in rural areas. Earlier, I provided information about some of the oldest respondents from Wielkopolska but I would also like to devote some attention to the oldest informants representing various regions in Poland (the two last columns of the table above have been removed).

Table 2. The oldest informants whose utterances are recorded and stored in the phonographic archive of the Dialectological Workshop of the AMU

\begin{tabular}{|c|c|c|c|c|c|c|}
\hline & Bukowska Wola & Miechów & Krakowskie & 307 & Andrzej Michalski & 1855 \\
\hline 1 & $\begin{array}{l}\text { Nowa Wieś } \\
\text { Królewska }\end{array}$ & Września & Wielkopolska & 2204 & Wincenty Szuba & 1860 \\
\hline 1 & Dąbrowa $\mathrm{p} \mathrm{W}$ & Wieluń & Lodz & 2255 & Marianna Kużniak & 1862 \\
\hline 1 & Mańkowice & Nysa & Opole & 2043 & Franciszek Hauke & 1864 \\
\hline 1 & Kałęczyn & Szczytno & Warmia-Masurian & 2056 & Ludorf Lota & 1866 \\
\hline 16 & Drawsko & Czarnków & Wielkopolska & 2156 & Małgorzata Smuga & 1866 \\
\hline 3 & Wyszyny & Chodzież & Wielkopolska & 2168 & Szczepan Wołyński & 1866 \\
\hline 1 & Morzewo & Chodzież & Wielkopolska & 2229 & Jan Wiorek & 1866 \\
\hline 1 & Wijewo & Leszno & Wielkopolska & 2155 & Elżbieta Jurowa & 1867 \\
\hline 1 & Królikowo & Żnin & Kuyavian-Pomer. & 2162 & Teodor Grabowski & 1868 \\
\hline 1 & Ławki & Mogilno & Bydgoszcz & 2038 & Józef Ljankowski & 1869 \\
\hline 1 & Stare Kramsko & Sulechów & Lubusz & 2134 & Anna Majer & 1869 \\
\hline 1 & Brzoza & Wieluń & Lodz & 912 & Marianna Stępień & 1869 \\
\hline 1 & Liwa & Ostróda & Warmia-Masurian & 2068 & NN mężczyzna & 1869 \\
\hline 2 & Liwa & Ostróda & Warmia-Masurian & 2089 & NN mężczyzna & 1869 \\
\hline 2 & Stawnica & Złotów & Wielkopolska & 2015 & Michał Weisstock & 1869 \\
\hline 1 & Kiełpiny & Wolsztyn & Wielkopolska & 2135 & Ludwik Rżanny & 1869 \\
\hline 5 & Wilkowyja & Jarocin & Wielkopolska & 2175 & Antoni Kubicki & 1869 \\
\hline 4 & Piaski & Gostyń & Wielkopolska & 2181 & Józefa Jemrychowa & 1869 \\
\hline 1 & Ogonki & Węgorzewo & Warmia-Masurian & 2061 & Herman Migge & 1870 \\
\hline 2 & Bańki & $\begin{array}{l}\text { Bielsk } \\
\text { Podlaski }\end{array}$ & Białystok & 313 & Józef Pęski & 1871 \\
\hline 1 & Biskupice & Mogilno & Bydgoszcz & 2030 & Wawrzyn Malicki & 1871 \\
\hline 1 & Łankowiczki & Szubin & Kuyavian-Pomer. & 2161 & Jan Najdul & 1871 \\
\hline
\end{tabular}

2 The personal data of the recorded and recording individuals have been published in catalogues of recordings (see Sobierajski 1957). 


\begin{tabular}{|c|c|c|c|c|c|c|}
\hline 1 & Kwaczała & Chrzanów & Krakow & 2006 & Jan Urbańczyk & 1872 \\
\hline 6 & Kluki & Slupsk & Pomorskie & 2122 & Henryk Kaitczik & 1872 \\
\hline 1 & Radosty & Olsztyn & Warmia-Masurian & 2064 & Anna Greichenberg & 1872 \\
\hline 1 & Wydawy & Rawicz & Wielkopolska & 358 & Marianna Rajczak & 1872 \\
\hline 2 & Wydawy & Rawicz & Wielkopolska & 359 & Marianna Rajczak & 1872 \\
\hline 1 & Dobieżyn & $\begin{array}{l}\text { Nowy } \\
\text { Tomyśl }\end{array}$ & Wielkopolska & 2174 & Agn. Łamaszewska & 1872 \\
\hline 1 & Kobylniki & Szamotuły & Wielkopolska & 2202 & $\begin{array}{l}\text { Matria } \\
\text { Kaczmarkowa }\end{array}$ & 1872 \\
\hline 1 & Topólno & Świecie & Kuyavian-Pomer. & 2234 & Ignacy Raniszewski & 1873 \\
\hline 1 & Ciemniki & Świecie & Kuyavian-Pomer. & 2238 & $\begin{array}{l}\text { Franciszek } \\
\text { Kopkowski }\end{array}$ & 1873 \\
\hline 1 & Rogojny & Olecko & Warmia-Masurian & 2059 & Gustaw Rogowski & 1873 \\
\hline 1 & Obłok & $\begin{array}{l}\text { Ostrów } \\
\text { Wlkp }\end{array}$ & Wielkopolska & 1616 & Antonina Zaręba & 1873 \\
\hline 1 & Parkowo & Oborniki & Wielkopolska & 2171 & Antoni Tabat & 1873 \\
\hline 1 & Lutogniew & Krotoszyn & Wielkopolska & 2177 & Franciszka Morgel & 1873 \\
\hline 1 & Kicko-Chełmce & Inowrocław & Bydgoszcz & 1307 & Wojciech Skowron & 1874 \\
\hline 2 & Kicko-Chełmce & Inowrocław & Bydgoszcz & 1308 & Wojciech Skowron & 1874 \\
\hline 2 & Piaski & Sieradz & Kuyavian-Pomer. & 2112 & Antonina Rychlik & 1874 \\
\hline 3 & Piaski & Sieradz & Kuyavian-Pomer. & 2113 & Antonina Rychlik & 1874 \\
\hline 1 & Stołuń & Międzyrzecz & Lubusz & 2130 & Leon Luka & 1874 \\
\hline 1 & Okalew & Wieluń & Lodz & 1628 & Stanisława Głuch & 1874 \\
\hline 1 & Lisia Góra & Słupsk & Pomerania & 2126 & Herman Szymanke & 1874 \\
\hline 1 & $\begin{array}{l}\text { Osława } \\
\text { Dąbrowa }\end{array}$ & Bytów & Pomerania & 2246 & Ignacy Kowalewski & 1874 \\
\hline 1 & Bzury & Pisz & Warmia-Masurian & 2147 & Jan Trynowała & 1874 \\
\hline 1 & Grodzisko & Strzelce & Lower Silesia & 2241 & Jan Gomuła & 1875 \\
\hline \multirow[t]{2}{*}{1} & Zboże & Sępólno & Kuyavian-Pomer. & 2235 & Jan Mudzik & 1875 \\
\hline & Wróblew & Wieluń & Lodz & 914 & $\begin{array}{l}\text { Marcjanna } \\
\text { Szymczewska }\end{array}$ & 1875 \\
\hline 1 & Narok & Niemodlin & Opole & 2110 & Stanisław Zdzuj & 1875 \\
\hline 1 & $\begin{array}{l}\text { Brzeżno } \\
\text { Gdańskie }\end{array}$ & Gdańsk & Pomerania & 2072 & Józef Rumczyk & 1875 \\
\hline 1 & Biała Piska & Pisz & Warmia-Masurian & 2148 & August Wiśniewski & 1875 \\
\hline 1 & Radawnica & Złotów & Wielkopolska & 2003 & Józef Glugla & 1875 \\
\hline 1 & Szkaradowo & Rawicz & Wielkopolska & 2142 & Maria Wormuth & 1875 \\
\hline 1 & Zielona Wieś & Rawicz & Wielkopolska & 2143 & Karol Bartkowiak & 1875 \\
\hline 1 & Lutomek & Międzychód & Wielkopolska & 2172 & Andrzej Jenek & 1875 \\
\hline 1 & Bachorzew & Jarocin & Wielkopolska & 2176 & $\begin{array}{l}\text { Antonina } \\
\text { Wierzchowicka }\end{array}$ & 1875 \\
\hline 4 & Żychlewo & Gostyń & Wielkopolska & 2223 & Marcin Nawrocki & 1875 \\
\hline
\end{tabular}


In an evaluation of the suitability of the Poznan record library in research into the oral Polish language, special attention should be paid to an episode accompanying an important achievement in Polish studies of dialects. The library of the Dialectologyl Workshop of the AMU includes records made simultaneously with the activities of the team managed by K. Nitsch. The recordings are excellent material for extending the characteristics of Polish dialects spoken in the second half of the 1950s. Back in 1953, "efforts were made to (...) include in the recordings informants whose dialects had already been used in questionnaires developed for the purpose of the "Small atlas of Polish dialects' published by the Polish Academy of Sciences" (Sobierajski 1957, 81). At that time, these were mainly villages in Wielkopolska and the adjacent areas: Drawsko, Czarnków county ${ }^{3}$; Wijewo, Leszno county; Piaski, Gostyń county; Środa area; Jancewo, Żnin county; Walentynowo, Wyrzysk county (Krajna and Bory). Later on, other informants were selected, residents of villages marked in the MAGP or sometimes an opportunity availed itself to record utterances of the respondents who provided material for the atlas. There are over a dozen of these villages, divided into dialects. These are ${ }^{4}$.

- Chełmno and Dobrzyń Land: Szczuka, Brodnica county;

- Silesia: Istebna, Cieszyn county; Olza, Wodzisław county;

- Małopolska: Więciorka, Myślenice county; Mokrzesz, Częstochowa county; Mrukowa, Jasło county; Chomęciska Duże, Zamość county; Niebieszczany, Sanok county; Chodów, Miechów county; Miedzna Murowana, Opoczno county; Ujanowice - Konary, Sandomierz county; Żelechlinek, Rawa Mazowiecka county;

- Masovia: Białka, Radzyń Podlaski county; Kadzidło, Ostrołęka county; Osuchowo Nowe, Ostrów Mazowiecka county; Uniszki Zawadzkie, Mława county;

- Podlasie: Bańki, Bielsk Podlaski county.

As far as I know, these materials have not been subjected to detailed analyses while they could provide lots of information facilitating more extensive characteristics of the local dialects. They have not been used as a valuable source in syntax-related studies. They are undoubtedly very valuable on many levels including a description of phenomena typical of other levels of linguistic analyses.

The phonographic collection of the Dialectology Workshop of the AMU contains more than 3,700 hours of recorded conversations with informants from various regions in Poland; there are also recordings made in the Polish diasporas in Kazakhstan and the Ukraine. A list of the hours of recordings (all of them now available in a digital version) is a derivative of a methodological assumptions that any conversation, even a very short one, should be registered. On the other hand, students often ask a question: "why do we do that if we cannot process it single-handedly?". We are of an opinion that in the face of a dynamic development (and transformation) of the Polish language, we need to supplement the research basis for the next generations. Generally speaking, we want to ensure that in 50 years' time, whoever wants to analyse the

\footnotetext{
3 The division into counties as per the then administrative division.

${ }^{4}$ In this specification, bolded are the names of the villages where a respondent was recorded who previously completed a questionnaire for the MAGP.
} 
course of developmental processes in the Polish language, will have at his/her disposal material indispensable for the analyses.

When researchers focus on a dialect spoken by a single rural community, to a large extent they can define the characteristic features of the community's language as it was spoken in specific time intervals. Many years of observing the speech of inhabitants of Bukówiec Górny (Leszno county) has resulted not only in extending the archive by more than 200 hours of conversations with approximately 70 individuals. This is a rare situation when a specific dialect is documented in utterances from so many speakers. Considering the generation factor has resulted in identifying disappearance of specific forms from the local dialect system - with reduplication of - $n$ - (mainly) in adjectives indicating materials like glinianny, drewnianny, wetnianny. This phenomenon could have been identified by adopting generational representation in selecting the interlocutors.

For the purpose of field explorations as well as specific analyses, we assume generational affiliation as indicated by the informant's year of birth. This is because we are certain that the complexity of a person's language is mostly affected by the time when his/her linguistic competence was acquired, the time of developing the language system together with the cultural references. For this reason (and for the purpose of clarity), to us generational affiliation is predominantly marked by the year of birth. We had many opportunities to (positively) verify this assumption in the course of numerous conversations with the same interlocutors.

For the purpose of clarity (the archive) and research, we have adopted the following generational division:

I. born before 1920. This generational group is practically no longer represented. This is a generation which developed its linguistic habits at home; it is also a generation whose language (Polish) was not affected by the school. In fact, this generation's language is best documented, presented on the maps of language atlases.

II. born in 1921-1945. When referring to the oldest generation, we deal with representatives of these years of birth. In rural areas, it is a group of people brought up in homogenous social and economic conditions. The informants from this interval are the main source of vocabulary related to the traditional organisation of rural life.

III. born in 1946-1970. The interlocutors from this generation grew up in different social and economic conditions, marked by gradual disappearance of the traditional rural structures and the conditions of traditional rural life. Their language has been largely affected by the school and human migration. Of importance is also the impact of the external factor - the unprecedented influence of the urban environment.

IV. born in 1971-1995. This generation is most diverse with respect to the conditions affecting their command of language. The social and economic transformations have left the deepest mark on them. The changes taking place in rural areas and brought about by external factors (including general electrification, water supply networks, different agricultural inputs etc.) which have contributed to a new reality, mainly on the vocabulary level.

V. born in 1996 and later. This generation grew up in the progressing transformation of the growth initiated by the previous generation. Observations of the language spoken by representatives of this generation lead to conclusions about the rate 
of linguistic changes that will take place in this group in the future. (Sierociuk 2003, 134).

The adopted generational division presented above makes it possible to carry out long-term research with the same informants. It also allows to make use of two parameters in research into evolutionary processes: the year in which a specific form was recorded and the informant's year of birth. In many cases, we can correctly interpret data obtained many years later in locations previously explored with specific tasks in mind. A case in point is confrontation of contemporary recordings and materials for the AJKLW, obtained in the first decade of the 1970s (Sobierajski 1972).

The Atlas języka i kultur ludowej Wielkopolski (AJKLW) [Atlas of Wielkopolska's folk language and culture ] has been compiled by two research teams from the AMU, dialectologists and ethnographers. The related questionnaire was developed by the circles of the Poznań dialectologists and ethnographers. The main contributors included chief editor Z. Sobierajski and dialectologists M. Gruchmanowa, H. Nowak and Z. Zagórski (Sobierajski 1972).

The AJKLW contains 889 maps grouped into subjects in 11 volumes. Therefore it provides a very exact picture of the linguistic and cultural diversity of the dialects spoken by inhabitants of Wielkopolska villages. The maps document the status of the dialect which now belongs to the past. Notably, a majority of the maps was developed by H. Nowak who should be deemed the major contributor to this part of the Atlas... (Sierociuk 2018).

While dialectal maps provide lots of information that enable to identify the specificity of the dialects in question, they fail to explain completely e.g. the importance of the mapped words. However, it is the dictionary that is used to present the semantics (meaning and contextual use) of dialectal words.

The first decade of the $21^{\text {st }}$ century was marked by a nearly complete exchange of the academic faculty and devising new research plans. In 2002, Prof. Henryk Nowak, manager of the Polish Dialectology Unit at the AMU, went into retirement. He devoted the last days of his life (he died in 2010) to continuing work on the Dictionary of the dialect of the Hazakis. His intention was to compile a comprehensive dictionary with an impressive lexicographic documentation presented in a very precise phonetic transcription. However, the work on the dictionary ended at the preliminary stage (Sierociuk 2018). By 2007 (the year of his death), Prof. Zenon Sobierajski was in charge of mainly organisational issues (related to publishing the AJKLW) (Walczak 2018c, Sierociuk 2020).

When the two professors passed away, attention had to be paid to recruiting personnel and outlining the research perspectives for the new young team. While the composition of the research team remained unchanged (three people: Prof. Jerzy Sierociuk, Ph.D., manager, and two students employed half-time), the academic side of the team was reinforced. Two people: Justyna Kobus, Ph.D. and Błażej Osowski, Ph.D., former students, have become independent scholars. Born in Wielkopolska, they will take care of the position of the Poznan dialectology in the years to come. Another opportunity will arise when more doctoral theses are defended in the Dialectology Workshop.

For many years, the circles of dialectologists (in Wielkopolska and elsewhere) have been plagued by lack of proper lexicographic documentation of the dialects spoken in 
Wielkopolska. An analysis of the material included in the SGP proves unambiguously that the dialect is least represented here. The need for filling this gap has been increasingly postulated not only by circles of lexicographers. After all, Wielkopolska dialects have largely contributed to the ultimate shape of the Polish literary language. What is more, the Polish statehood was achieved in the area.

The aforementioned Dictionary of Polish Dialects (SPG) from Krakow provides a distinct picture of the lexical abundance of dialects. In evaluations of the achievements of dialectal lexicography, there are many unfavourable comments about the Poznań dialectology. This is because the Wielkopolska dialect is very modestly represented in the SGP files ("Wielkopolska is poorly represented not only in the SPG but even in the contemporary SGPPAN" - Karaś 2011,58). Bearing in mind the fact that the Krakow files contain confirmations of uses of dialectal words, including words from the $19^{\text {th }}$ century, the shortages of Wielkopolska documentation (especially postwar) are of special importance. In many cases, the fact distorts the overall picture of the dialectal phenomena developed on the basis of the files. In this situation there is a danger of interpreting some phenomena as developing independently (bearing in mind the lack of documentation from the Wielkopolska zone in the light of abounding documents from the north and south of Poland).

The SGP files do not offer many excerpts from dialectal texts (or studies thereof) related to Wielkopolska; simply, they are not to be found in the region. In this situation, researchers need to resort to hand-written materials. These are not particularly abundant, either: a list of sources (SGP 1977) provides information that allows to outline the lexicographic representation of the specific regions: the name of the village and the location (including the number in the county), the explorer's name and the year of his/her record plus a number of submitted sheets. A similar procedure was adopted by the editors who first provided information about the delivered supplementary materials. Starting with issue 16 (reorganisation of editorial work), this data is not provided. When these materials are compiled, the resulting picture is quite surprising. I will present only data related to a single county (Gniezno) which is of importance in the context of the lexicographic ventures launched in the Dialectology Workshop (to be elaborated on):

\section{GNIEZNO}

Gniezno (no number in issue 16) - Adam Tomaszewski, 1930-1932, 5 sheets

1. Czerniejewo - Adam Tomaszewski, 1930-1932, 10 sheets

2. Dąbrówka Kościelna - Adam Tomaszewski, 1930-1932, 10 sheets

3. Dębłowo - Adam Tomaszewski, 1930-1932, 10 sheets

4. Dębnica - Adam Tomaszewski, 1930-1932, 10 sheets

5. Dziekanowice - Adam Tomaszewski, 1930-1932, 10 sheets

6. Imiołki - Adam Tomaszewski, 1930-1932, 10 sheets

7. Kamieniec - Adam Tomaszewski, 1930-1932, 10 sheets

8. Kiszkowo - Adam Tomaszewski, 1930-1932, 10 sheets

9. Mielżyn - Adam Tomaszewski, 1930-1932, 10 sheets

10. Niechanowo - Kazimierz Nitsch, 1904-1939, 50 sheets

Adam Tomaszewski, 1930-1932, 10 sheets 
11. Ostrowite Prymasowskie - Adam Tomaszewski, 1930-1932, 10 sheets

12. Powidz - Adam Tomaszewski, 1930-1932, 10 sheets

13. Skorzęcin - Adam Tomaszewski, 1930-1932, 10 sheets

14. Strzyżewo - Adam Tomaszewski, 1930-1932, 10 sheets

15. Ujazd - Adam Tomaszewski, 1930-1932, 10 sheets

16. Węgorzewo - Adam Tomaszewski, 1930-1932, 10 sheets

17. Wierzyce - Adam Tomaszewski, 1930-1932, 10 sheets

18. Witkowo - Adam Tomaszewski, 1930-1932, 10 sheets

This type of list does not allow to follow historical changes and highlights a lack of bases for characterising the abundance of the vocabulary. There is a need for intensifying field research as a result of which a dictionary of dialects is compiled - even if a complex of dialects is small. It is of importance in the context of Wielkopolska because dialectologists from various centres in Poland have postulated such works:

Lately, we have seen intensified research into the vocabulary of the Polish language spoken in the former Eastern Borderlands (14 dictionaries). There is a number of regions which urgently need these dictionaries. They include Wielkopolska proper and Masovia proper including Kurpie and Podlasie (Karaś 2011, 293).

Prof. Witold Doroszewski, a prominent Polish linguist used to say that the biggest problem of dialectology is "shortage of labour". Typically, teams of dialectologists are small, independent while complete collection of material in the field oftentimes is beyond their capabilities. In this situation, it is imperative to refer to the assistance of the local communities. For several years, the Dialectology Workshop of the Institute of Polish Philology of the Poznań University has been involved in this type of activity. Most typically, the local partner is a school where a group of pupils get involved in obtaining linguistic material. This is a way of reaching interlocutors (informants) who know (often only passively) the specific names or observe specific customs. The involved explorers (in this case, pupils from a specific school) follow our guidelines. Each time, we try to prepare the team of young explorers; at preliminary meetings, we discuss the way and range of activities. The available devices register entire conversations; the pupils tend to use their cellular phones. The recordings are sent to the Workshop where they are further treated: transcribed (writing down the recording) and further processed with respect to the content.

The cooperating representatives of the local communities receive content-related guidelines and a set of questions (a questionnaire) intended to serve as the basis for the conversation. Since pupils tend to be less interested in the idiosyncrasies of the local language (typically we ask about the names of specific activities or objects), the questionnaire contains questions of various "degrees of accuracy". For example, in order to examine words related to butter production, we first ask how butter is made. Depending on the interlocutor's "openness", at this stage we can register an utterance containing words about which we did not ask in a specific questionnaire. This also

5 Similarly in (Reichan, Woźniak 2001). 
poses an opportunity of documenting uses of very rare words, oftentimes unknown to dialectologists. Only later do we ask specific questions, e.g. what is a kierzynka, what parts does a kierzynka consist of, about the liquid remaining in a kierzynka when butter is extracted etc. In this part of the questionnaire, we also introduce questions about the "meaning" of specific words, e.g. what a "podchlebiajek" is ("the top part of a kierzynka ...'). We do realise that this word is unfamiliar in many places because it was never used there or it has been "forgotten". Negative replies ("I don't know it", "people don't say it here") are of special importance to the general characteristics of a local dialect. When confronted with the accumulated knowledge (e.g. a comparison with the AJKLW maps) they can also confirm the rate of changes taking place in a local dialect.

At the same time, we try to obtain photographic documentation; in the case of referents quickly "leaving collective memory", for many future readers (even readers of the dictionary) this is the only opportunity to confront one's image and the "historical documentation". Let me emphasise that due to the linguistic changes taking place in rural areas, instead of referring to a dialect we prefer a phrase the language spoken in rural areas (Sierociuk 2007).

As I have indicated before, in comparison with other dialects, Wielkopolska's lexicographic documentation is the most deficient. The above presented activities are aimed at bridging the gap, even partially. The ventures launched in the Dialectology Workshop at the AMU have resulted in publishing several dictionaries within a series "Wielkopolska Regional Dictionaries" in response to the major premise aligned with the following assumptions:

- documenting and propagating a dialect from a small area aimed at raising regional awareness; with this assumption, the dictionaries are addressed chiefly at the local communities which oftentimes think of this kind of activity as following the rule "about us - for us". The vocabulary of a specific thematic range is preceded by information about the area (e.g. a study of the history) and the cooperating school. Undoubtedly, this is a specific way of promoting a region and its culture bearing in mind that each entry is illustrated by ample documentation including fragments of the informants' authentic utterances (if possible, supplemented by the referent's photograph);

- thematic diversity of the dictionaries according to a general rule which says that a specific set (a thematic dictionary) represents a concrete dialectal set (e.g. eastern Wielkopolska, central Wielkopolska etc.); this poses an opportunity to attempt to explain the complicated lexical structure of the entire complex of Wielkopolska dialects. The thematic "diversity" of dictionaries representing the same area is aimed at presenting, at least partly, the lexical abundance of Wielkopolska dialects. In long terms, they are to form the basis for a general Wielkopolska dictionary. The way in which the words are presented takes into account compilation of two versions of the dictionary: printed (now) and electronic (online) in the future;

- the scholarly value comes down not only to ample documentation; the dictionary also contains several words loosely related (with respect to the subject) to the rest of the collection. It is about making available information of importance to academic analyses, e.g. the history of the Polish language or even to the interpretations of some (general) Slavic phenomena. Consequently, a regional dictionary has readers far beyond the local community. 
With the local readers in mind, dictionaries of dialects provide a simplified transcription. We assume that the plane of reference here is a record referring to the rules of general writing; onto these phenomena, dialectal peculiarities are "superimposed". We have not introduced delimitation of text which comes down to separating syntactic sections by means of comas and dots as a signal of the end of a sentence. We try to reflect the speed of speech by marking pauses with ... (the ellipsis). In brackets, an abbreviation is placed of the village where a quotation comes from or where the word was registered. An entry is supplemented by references to synonymous forms. All the forms contained in a specific dictionary are printed in bold, even if they have been used in a definition of an entry. This rule is supplemented by italics used to indicate material obtained in the field from informants. A regular font is used in the parts written by the authors - explanation of the meaning or insertions which make it easier to understand a specific fragment of an utterance.

As an example, let me present three entries from the dictionary of the Łuków area (Sierociuk 2019a):

harfa - 'tu: pochylnia zrobiona z ułożonych podłużnie szczebelków, zazwyczaj do wrzucania kartofli do piwnicy': do piwnicy kartofle zrzucano ... byly otwory ... takie okna ... $i$ robiło sie takie ... żeby to byto doste ${ }^{m} p$ do kartofly ... taki $z$ drewna ... takie szczebelki ... i po tych szczebelkach kartofle leciaty przez te (!) okienko do piwnicy ... taki stojak ... jak coś takiego ... przez to leciało ... do kartofly przerzucania to jes harfa ... (Grz); zob. rafka.

kogutek - 'ustawione w polu snopki': zebrać go ... zwionzać ... zestawić ... w kogutki ... (Żył); kogutki to u nas sie nazywaty ... (Żył); zob. dziesiontek, kopa, kopica, kopka 2, kupka 3, mandel, mendelek, myndel.

młynkować - 'oczyszczać zboże młynkiem': najpierw to byty co nie wiała ... tylko tyle co wymłóciła ... i z plewami wszystko szło do wialni ... późni trzeba było młynkować ... a były ... późni już byty ... co oddzielaty ... wiaty ... (Grz); mtynkować ... (Chr); jak sie młócito wiejko maszyno ... to nie trza było wiać ... a targanko ... i prostomtotno to byta wialnia ... trzeba jo było wialnio ... i późnij mlynkować ... na przykład ... trzeba było ... (Żył).

According to the above rules, seven volumes of the Wielkopolska Regional Dictionaries have been completed to date, one of them recently submitted for publishing (see the list below), others being compiled. The accessibility of the suggested form of presenting dialect material leads to many local communities expressing their willingness to cooperate by stating "we want a dictionary like this, too".

When speaking about dialectology in Poznań, we mustn't disregard the developing cooperation with numerous foreign centres. This comes down mainly to exchanging the theoretical assumptions and specific achievements in field studies; they are presented at international conferences. As a result of the idiosyncrasies of the inquiries on the part of Slavic dialectology, the related cooperation develops mainly with centres accompanying national academies of sciences. The circle of Poznań dialectologists appreciates very much direct contacts - exchange of academic literature and participation in conferences (often co-organised) - with colleagues from academic institutes in 
Russia (Sankt Petersburg and Moscow), Ukraine (Kiev and Lvov), Bulgaria (Sophia), the Czech Republic (Brno). More and more frequently, academic contacts are made with representatives of dialectological centres from other countries. The growing scholarly exchange with foreign universities is also worth mentioning.

The Dialectology Workshop at the AMU has organised (or co-organised with the Poznań Society for the Advancement of Arts and Sciences and other linguistic workshops at the AMU) two regular conferences attended by an increasing number of foreign speakers. "Gwary dziś" used to be an editorial series published by the Society, since 2001 resulting in papers previously delivered at conferences as part of the same series. The integration of the circles of Slavic dialectologists has resulted in transforming the series into an online annual dedicated to Slavic dialectology which since 2015 has been an informal body of the Dialectology Committee at the International Committee of Slavists. It is available as "Gwary Dziś" under http://gwary.ptpn.poznan.pl/pl/index-pl/ or https://pressto.amu.edu.pl/index.php/gd. Since 2014, every two years, we also (co)organise a conference on "Language in a region - a region in language". The materials are published under the same title (the first volume was published in Poznań in 2016.).

Important online addresses:

http://dialektologia.amu.edu.pl/index.htm

dialektologia@amu.edu.pl

Wielkopolska Regional Dictionaries:

Kobus J., Gniazdowski T. (ed.) (2018), Słownik języka mieszkańców okolic Gniezna. Święta, wierzenia i przesądy, Poznań.

Kobus J., Stępień M. (ed.) (2018), Stownik języka mieszkańców Czerniejewa. Praca na roli $i$ gospodarstwie, Poznań.

Kobus J., Migdałek A. (ed.) (2021), Słownik języka mieszkańców okolic Pobiedzisk. Praca na roli $i$ w gospodarstwie, Poznań (being printed).

Osowski B. (ed.) (2018a), Gospodarz. Słownik języka mieszkańców powiatu kolskiego, Poznań.

Osowski B. (ed.) (2018b), Gospodyni. Słownik języka mieszkańców powiatu kolskiego, Poznań.

Osowski B. (ed.) (2019), W kuchni u pleszewian. Słownik języka i kultury mieszkańców powiatu pleszewskiego, Poznań.

Sierociuk J. (ed.) (2019a), Słownik języka mieszkańców ziemi łukowskiej. Praca na roli $i$ w gospodarstwie, Poznań.

\section{Bibliography}

AJKLW - Atlas języka i kultury ludowej Wielkopolski, vol. I-VI,. Z. Sobierajski and J. Burszta (eds.), Wrocław [at al.] 1979-1991, vol. VII-XI. Z. Sobierajski (ed.), Wrocław [et al.] - Poznań 1992-2005.

Gliszczyńska A. (2007), Germanizmy leksykalne w Atlasie języka i kultury ludowej Wielkopolski, [in:] Gwary dziś. 4. Konteksty dialektologii, J. Sierociuk (ed.), Poznań, pp. 275-286. 
Gruchmanowa M. (1970), Gwary zachodniej Wielkopolski, Poznań.

Jędraszewski W., Szczepaniak M. (2010), Leksykon miejscowości Wielkiego Księstwa Poznańskiego, issue 1 - Powiat Gniezno, Gniezno.

Kaniewska B. (2018), O początku i nie tylko, [in:] Stulecie poznańskiej polonistyki (1919-2019), vol. 1. Okres międzywojenny i lata okupacji, B. Judkowiak, S. Wysłołuch, S. Karolak, A. Piotrowicz (eds.), Poznań, pp. 11-18.

Karaś H. (2011), Polska leksykografia gwarowa, Warszawa.

Kobus J. (2017), Dokumenty Archiwum UAM dotyczace doc. Adama Tomaszewskiego, "Gwary Dziś” 9, pp. 209-213; http://gwary.ptpn.poznan.pl/wp-content/uploads/2019/12/Gwary-9-12Kobus.pdf.

Kolberg O. (1875-1882), Lud. Jego zwyczaje, sposób życia, mowa, podania, przysłowia, obrzędy, gusła, zabawy, pieśni, muzyka i tańce. Przedstawił Oskar Kolberg. Serya IX. W.Ks. Poznańskie. Parts 1-7, Kraków.

Lewaszkiewicz T. (2018), Adam Tomaszewski (1895-1945) - poznański dialektolog, [in:] Stulecie poznańskiej polonistyki (1919-2019), vol. 1. Okres międzywojenny i lata okupacji, B. Judkowiak, S. Wysłołuch, S. Karolak, A. Piotrowicz (eds.), Poznań, pp. 291-304.

Maciejewski J. (2018), Uniwersyteckie tradycje filologii polskiej w Poznaniu, [in:] Stulecie poznańskiej polonistyki (1919-2019), vol. 1. Okres międzywojenny i lata okupacji, B. Judkowiak, S. Wysłołuch, S. Karolak, A. Piotrowicz (eds.), Poznań, pp. 21-61.

MAGP - Maty atlas gwar polskich, oprac. Pracownia Dialektologiczna (from volume IV Pracownia Atlasu i Słownika Gwar Polskich) Zakładu Językoznawstwa PAN w Krakowie, vol. I-II under the guidance of K. Nitsch, vol. III-XIII under the guidance of M. Karaś, Wrocław - Kraków 1957-1970.

Malepszak S. (2007), Bukowiec Górny. 800 lat dziejów, Bukowiec Górny.

Nowak H. (2001), Od Archiwum Fonograficznego do Zakładu Dialektologii Polskiej Uniwersytetu im. Adama Mickiewicza w Poznaniu, [in:] Gwary dziś. 1. Metodologia badań, J. Sierociuk (ed.), Poznań, pp. 201-212.

Piwowarczyk D.R. (2020), Kazimierz Nitsch - współtwórca językoznawstwa polskiego, [in:] My z Nich, 4. Spuścizna językoznawców polskich XX wieku, Z. Greń, K. Kleszczowa, Z. Zaron (eds.), Warszawa, pp. 129-140.

Reichan J., Woźniak K. (2001), Perspektywy polskiej leksykografii gwarowej, [in:] Gwary dziś. 1. Metodologia badań, J. Sierociuk (ed.), Poznań, pp. 33-42.

SGP - Słownik gwar polskich (opracowany przez Zakład Dialektologii Polskiej Instytutu Języka Polskiego PAN w Krakowie), vol. I, issue 1. (A-Algiera), Wrocław-Warszawa-KrakówGdańsk-Łódź. 1979 - vol. X, issue 33 (I-Iżyna), Kraków 2019.

SGP 1977, Słownik gwar polskich, opracowany przez Zakład Dialektologii Polskiej Instytutu Języka Polskiego PAN w Krakowie. Źródła, Wrocław-Warszawa-Kraków-Gdańsk.

Sierociuk J. (2003), Założenia metodologiczne badań języka wsi, "Poznańskie Spotkania Językoznawcze”, vol. XI, Z. Krążyńska, Z. Zagórski (eds.), Poznań, pp. 13-136.

Sierociuk J. (2005), Z zasobu polskiego stownictwa: Murzyn, [in:] Ad perpetuam rei memoriam. Profesorowi Wojciechowi Ryszardowi Rzepce z okazji 65. urodzin, Poznań, pp. 369-374.

Sierociuk J. (2007), Język mieszkańców wsi czy gwara? Problem nie tylko teoretyczny, "Prace Filologiczne", vol. LIII, Warszawa, pp. 527-534. 
Sierociuk J. (2013), W sprawie wielkopolskiej polszczyzny regionalnej, [in:] Cum reverentia, gratia, amicitia ... Ksiegga jubileuszowa dedykowana Profesorowi Bogdanowi Walczakowi, J. Migdał, A. Piotrowska-Wojczak (eds.), vol. III, Poznań, pp. 205-211.

Sierociuk J. (2018), Henryk Nowak (1932-2010) - cichy dialektolog, [in:] Stulecie poznańskiej polonistyki (1919-2019), vol. 2. Językoznawstwo (po roku 1945), A. Piotrowicz, S. Wysłouch, B. Judkowiak, S. Karolak (eds.), Poznań, pp. 237-248.

Sierociuk J. (2019b), Gwara - nasz język, nasze dziedzictwo, "Przegląd Wielkopolski", no. 3 (125), pp. 4-12.

Sierociuk J. (2020), Zenon Sobierajski - poznański dialektolog, [in:] My z Nich, 4. Spuścizna językoznawców polskich XX wieku. Z. Greń, K. Kleszczowa. Z. Zaron (eds.), Warszawa, pp. 185-200.

Sobierajski Z. (1957), Katalog ptytoteki Zakładu Fonograficznego UAM, part II, "Biuletyn Fonograficzny" 2, pp. 81-109 + map.

Sobierajski Z. (1972), Kwestionariusz do Atlasu języka i kultury ludowej Wielkopolski, cz. I: Stownictwo - Fonetyka - Stowotwórstwo, questions 1-645 (cooperation: M. Gruchmanowa, H. Nowak, Z. Zagórski); part II: Deklinacja - Koniugacja - Składnia, questions 646-1380 (cooperation: M. Gruchmanowa, H. Nowak); part III: Etnographica, questions 1381-1953 (supplements: T. Wróblewski); part IV: Ilustracje, Poznań.

Walczak B. (2018a), Edward Klich (1878-1939) - językoznawca. Życie i twórczość naukowa, [in:] Stulecie poznańskiej polonistyki (1919-2019), vol. 1. Okres międzywojenny i lata okupacji, B. Judkowiak, S. Wysłołuch, S. Karolak, A. Piotrowicz (eds.), Poznań, pp. 249-260.

Walczak B. (2018b), Wojciech Ryszard Rzepka na tle poznańskiej tradycji językoznawstwa, [in:] Stulecie poznańskiej polonistyki (1919-2019), vol. 2. Językoznawstwo (po roku 1945), A. Piotrowicz, S. Wysłouch, B. Judkowiak, S. Karolak (eds.), Poznań, pp. 303-314.

Walczak B. (2018c), Zenon Sobierajski (1917-2007) - slawista i dialektolog, znawcza gwar polskich i słowiańskich, [in:] Stulecie poznańskiej polonistyki (1919-2019), vol. 2. Językoznawstwo (po roku 1945), A. Piotrowicz, S. Wysłouch, B. Judkowiak, S. Karolak (eds.), Poznań, pp. 191-209.

Wikarjak J. (ed.) (1972), Uniwersytet Ziem Zachodnich i tajne kursy uniwersyteckie 1939-1945. Pokłosie wspomnień, Poznań.

Zagórski Z. (1967), Gwary pótnocnej Wielkopolski, Poznań.

Zagórski Z. (2011), Językoznawstwo polskie na Uniwersytecie im. Adama Mickiewicza w latach 1919-2009 (w zarysie), Poznań. 